\title{
Sense Relations in the Treatment of Meaning in Isichazamazwi SesiNdebele
}

Eventhough Ndlovu, Department of African Languages and Literature, University of Zimbabwe, Harare, Zimbabwe (endlovu@arts.uz.ac.zw)

\begin{abstract}
This article evaluates how meaning has been treated in Isichazamazwi SesiNdebele (2001) through the application of the sense relations hyponymy, meronymy and synonymy. It attempts to establish the adequacy of meaning presentation in definitions given to headwords. It assesses how the application of sense relations contributes to the user-friendliness of the definitions, the accessibility of the dictionary contents and the semantic analysis of lexemes in dictionaries. It aims to give insights that will help refine and improve future dictionary definitions. The article reveals that hyponymy and meronymy facilitate the formulation of more user-friendly and accessible dictionary definitions. On the other hand, synonym definitions reduce the user-friendliness and accessibility of the definitions in dictionary types that are not dictionaries of synonyms. As dictionary making is a part or a form of standardizing a language, it ought to be as accurate as possible in the presentation of semantic facts which is a reflection of the cultural values and ideologies of the society.
\end{abstract}

Keywords: HYPONYMY, MERONYMY, SYNONYMY, USER-FRIENDLY, ACCESSIBILITY, DEFINING FORMAT, DEFINING PRINCIPLE, CIRCULARITY, ONOMASIOLOGICAL, SEMASIOLOGICAL, CROSS-REFERENCING

Opsomming: Betekenisverwantskappe in die behandeling van betekenis in Isichazamazwi SesiNdebele. Hierdie artikel beoordeel hoe betekenis in Isichazamazwi SesiNdebele (2001) behandel is deur die aanwending van die betekenisverhoudings hiponimie, meronimie en sinonimie. Dit probeer om die toereikendheid van betekenisaanbieding vas te stel in definisies wat aan trefwoorde gegee is. Dit bepaal hoe die aanwending van betekenisverhoudings bydra tot die gebruikersvriendelikheid van die definisies, die toeganklikheid van die woordeboekinhoud en die semantiese inhoud van lekseme in woordeboeke. Dit beoog om insigte te bring wat sal help om toekomstige woordeboekdefinisies te verfyn en te verbeter. Die artikel toon dat hiponimie en meronimie die formulering van gebruikersvriendeliker en toegankliker woordeboekdefinisies vergemaklik. Aan die ander kant verminder sinoniemdefinisies die gebruikersvriendelikheid en toeganklikheid van die definisies in woordeboeksoorte wat nie sinoniemwoordeboeke is nie. Omdat woordeboekmaak ' $n$ deel of 'n vorm van die standaardisering van ' $n$ taal is, behoort dit so noukeurig as moontlik te wees in die aanbieding van semantiese feite wat ' $n$ weerspieëling van die kulturele waardes en ideologieë van die maatskappy is.

Sleutelwoorde: HIPONIMIE, MERONIMIE, SINONIMIE, GEBRUIKERSVRIENDELIK, TOEGANKLIKHEID, DEFINIËRINGSFORMAAT, DEFINIËRINGSBEGINSEL, SIRKULARITEIT, ONOMASIOLOGIES, SEMASIOLOGIES, KRUISVERWYSING 


\section{Introduction}

Definitions are probably the most central information in a dictionary, and most users consult a dictionary more for definitions than for any other information presented in it. Most critics of dictionaries therefore focus mainly on definitions. Because of the importance of definitions, it is necessary to establish defining formats and principles that will help formulate more user-friendly and accessible dictionary definitions adhering to the essential principles of defining. This article looks at how the sense relations hyponymy, meronymy and synonymy can contribute to definitions which avoid circularity, define the entry word, define every word used in the definition and avoid using words more difficult to understand than the entry word. In short, the article assesses the contribution(s) any sense relations make towards the semantic analysis of lexemes and phrases in lexicography.

Sense relations are concerned with the meaning relations words contract with each other in the meaning system of the vocabulary of a language (Lyons 1977: 241). It deals with meaning relations within the vocabulary system of the language. Jackson (1988: 43) defines sense relations as meaning relations between words themselves, a complex system of relationships that exist between the linguistic elements themselves. Sense relations are therefore the intralinguistic relations of lexical items making up the vocabulary of a language.

\section{$2.1 \quad$ Hyponymy}

According to Jackson (1988: 65), hyponymy refers to the hierarchical relationship between the meanings of lexemes, in which the meaning of one lexeme is included in or under the meaning of another lexeme. Lyons (1977: 242) defines hyponymy as a less familiar relationship that refers to a relation of inclusion, whereby one can say that an $X$ is a kind of $Y$. Hyponymy is the relation between more specific (hyponymous) terms and less specific (superordinate) terms. According to Crystal (1995: 105), the more general term is called the superordinate or hypernym, and the less general ones are hyponyms.

Hypernyms and hyponyms relate to each other through a hierarchical relation of generality and specificity. Hyponymy is thus a notion that refers to the meaning relation of inclusion of meaning of specific terms into more general terms. This can be illustrated by the following examples: indlondlo (green mamba) is a hyponym of imamba (mamba), a hyponym of izinyoka (snakes), a hyponym of omahuquza (reptiles) and iphimpi elimhlophe (white cobra) and iphimpi elingumdaka (grey cobra) are hyponyms of iphimpi (cobra), a hyponym of omahuquza (reptiles). If these hyponyms share the same hypernym they are called co-hyponyms. According to this, indlondlo (green mamba) and imamba emnyama (black mamba) are co-hyponyms of the hypernym imamba (mamba), and iphimpi elimhlophe (white cobra) and iphimpi elingumdaka (grey cobra) of the 
hypernym iphimpi (cobra), while imamba and iphimpi are co-hyponyms of the hypernymic term izinyoka (snakes), which in turn is a hypernym of omahuquza (reptiles).

Crystal (1995: 105) notes that much of the vocabulary of a language is linked by such systems of inclusion which yield semantic networks forming the hierarchical taxonomies. The hierarchical ordering of lexemes can be represented formally using tree diagrams such as the following:

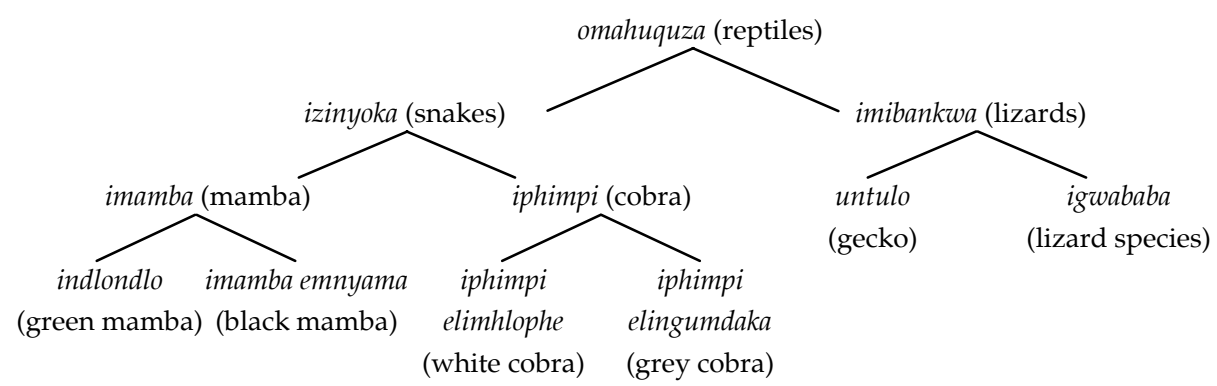

The notion of inclusion contained in the above definition of hyponymy, can be illustrated with the following entry from ISN:

iphimpi bz 5. Iphimpi luhlobo lwenyoka encane, elobuhlungu njalo empofu ngokunsundu. Yande ukutholakala endaweni ezilamatshe.

(cobra noun cl 5. A cobra is a type of a small snake that has venom and is dark brown in colour. It is usually found in rocky areas.)

In definition (1), the sense of iphimpi (cobra) is included in the sense of inyoka (snake).

Hyponymy involves entailment, for example to say leli liphimpi (this is a cobra) entails that it is an inyoka (snake) and an umahuquza (reptile). To say yinsumbelume (he is one who is past the normal or expected age of marrying) entails that he is a human being and specifically a man, and means that kathathanga or kalamfazi (he is unmarried). The involvement of entailment in hyponymy forms, according to Palmer (1981: 87), the basis of Carnap's meaning postulates, where it is suggested that the meaning of lexical items can be stated in terms of such entailments. Hyponymy is therefore defined in terms of a one-way entailment. Thus, if one says lo ngumthakathi (this is a witch/wizard), it entails that she/he is a human being and means that ukuthi umuntu uyaloya (the person practises witchcraft). From this example it can be deduced that being a witch/wizard is hyponymous to being a human being and synonymous with practising witchcraft. Saying le yinyumba (this one is barren) entails that she is a female human or animal and means that kazali (she is unable to conceive). Here, being barren is hyponymous to being a female human or animal and synonymous with being unable to conceive. If the idea of entailment involved in hyponymy is followed, inyumba (barren female human 
or animal) could be defined as in the following example proposed by the author.

(2) inyumba bz 9. Inyumba ngumuntu wesifazana ongazaliyo loba inyamazana ensikazi engazaliyo.

(barren female human or animal noun cl 9. A barren female human or animal is a female human or animal unable to conceive.)

In view of the idea of entailment involved in hyponymy, Palmer (1981: 87) concludes that hyponymy can be defined in such a way that synonymy counts as a special case of hyponymy. Recognizing this relationship between hyponymy and synonymy, Carter (1998: 21) interprets hyponymy as a kind of asymmetrical synonymy. The two synonyms yinyumba (is barren) and kazali (is unable to conceive) are co-hyponyms of "is a female umuntu (human) or inyamazana (animal)", hence synonymy can be regarded as a special case of hyponymy.

Hyponymy is a transitive relation, meaning that it can be seen 'in transit' all along the line so that if $X$ is a hyponym of $Y$ and $Y$ is a hyponym of $Z$, then $X$ is a hyponym of $Z$ (Saeed 2003: 69). For example, if igwababa (a lizard species) is a hyponym of imibankwa (lizards) and imibankwa is a hyponym of omahuquza (reptiles), then igwababa is a hyponym of omahuquza. The fact that hyponymy is transitive therefore means that a specific lexeme is a hyponym of any other lexeme that dominates it in the tree as shown in the diagram above.

Hyponymic relations vary from language to language, for example, in English a tomato and a potato are included under vegetables but in ISN itamatisi (tomato) and igwili (potato) are both defined as isihlahlakazana (shrub) not as umhlobo wembhida (type of vegetable). The word imibhida (vegetable) refers specifically to leaf and green vegetables.

There are, however, some lexemes that do not have any hyponymic relations, so that trying this formula for these lexemes results in somewhat vague and all-inclusive general terms such as those denoting state, place or thing. Abstract nouns as well as verbs and adjectives are among the most difficult in this respect. For example, is umsindo (noise) a kind of umdumo (sound) or is umdumo (sound) a kind of umsindo (noise)? In these cases, the level of abstraction is difficult to determine.

\subsection{Meronymy}

According to Saeed (2003: 70), meronymy refers to part-whole relationships between lexical items. Meronymy involves defining lexemes by saying that something forms part of something else or something contains or possesses something else. Saeed explains this relationship using the sentence frame: $X$ is part of $Y$ or $Y$ has $X$. It can therefore be said that the ingono (nipple) is part of the ibele (breast) and the ucilikicane (little finger) is part of isandla (hand) or the ibele (breast) has an ingono (nipple) and the isandla (hand) has an ucilikicane (little finger). Apart from saying yingxenye, one can say yisitho somzimba (it is an 
organ/a part of the body), yisiqa se ... (it is a piece/a part of ... ) or lucezu lwe ... (it is a part of or a piece of ...), which all capture meronymy.

According to Crystal (1995: 107), meronymy reflects hierarchical classifications in the lexicon somewhat similar to taxonomies, but the hierarchies of meronymy are less clear-cut and regular than those of taxonomies. Meronyms vary in terms of how necessary the part is to the whole. Networks identified as meronymy are therefore lexical, that is, it is conceptually possible to segment an item in countless ways, but only some divisions are coded in the vocabulary of a language.

Hyponymy and meronymy therefore differ in terms of transitivity. As illustrated earlier in the article, hyponymy is always transitive but meronymy may or may not be. In other words, meronymy is not consistently transitive in the way hyponymy is. For example, despite the fact that umunwe (finger) is a meronym of isandla (hand) and isandla (hand) a meronym of ingalo (arm), one might have some hesitation about the statement umunwe (finger) is a part of ingalo (arm). A transitive example of meronymy can be illustrated by positing the following: uzipho (finger nail) is part of umunwe (finger), and umunwe (finger) is part of isandla (hand), so uzipho (nail) is therefore part of isandla (hand).

\subsection{Synonymy}

According to Jackson (1988: 66), two words can be described as synonyms if they can be used interchangeably in all sentence contexts. Saeed (2003: 65) defines synonyms as different phonological words having the same or very similar meaning. Likewise Yule (2006: 104) describes synonyms as two or more forms with very closely related meaning(s), which are often, but not always, intersubstitutable in sentences. In a general and broader sense, synonymy is a relation of sameness of meaning.

From the above observations, one notes that apart from the sameness of meaning involved in synonymy, synonymy is a matter of degree, which therefore yields two types of synonyms: absolute, strict, true or total synonyms and partial, loose or near synonyms. Matthews (1997: 327) defines absolute synonyms as those having meanings identical in all respects and contexts, for example -jonga/-hlosa (resolve), -jwamula/-hluthuna (snatch), and -qila/-dlelezela (cheat). Partial synonyms are those having meanings identical in some contexts or identical only as far as replacing one with the other does not change the truth conditions of a sentence, for example -zimuka/-nona (get fat), and -zala/ -khululeka (give birth). These are partial synonyms, because replacing one with the other does not change the truth condition of the sentence but they cannot be used interchangeably in all contexts, because the rules of usage are not similar and the rules of predication and reference are not the same in habitual texts. The interchangeability of partial synonyms can cause embarrassment to both speakers and listeners, for example: 
(3) (a) Inkazana izithwele. (The girl is pregnant.)

(b) *Inkomo izithwele. (*The cow is pregnant.) (i.e. of a human being)

(c) Inkomo imithi. (The cow is in calf.)

(d) *Inkazana imithi. (*The girl is pregnant.) (i.e. of an animal)

(4) (a) Inkazana ikhululekile. (The girl gave birth.)

(b) *Inkomo ikhululekile. (*The cow gave birth.) (i.e. of a human being)

(c) Inkomo izele. (The cow calved.)

(d) ${ }^{*}$ Inkazana izele. $\left({ }^{*}\right.$ The girl gave birth.) (i.e. of an animal)

Palmer (1981: 89) notes that there are few absolute or real synonyms in natural languages. Similarly Ullmann (1962: 142) asserts: "Very few words are completely synonymous in the sense of being interchangeable in any context without the slightest alteration in objective meaning, feeling-tone or evocative value."

Yule (2006: 104) explicates that it is usually possible to find some nuances that separate synonyms or contexts in which one of the lexemes can appear, but the other(s) cannot. Therefore, when this fact is taken into consideration, it becomes clear that absolute synonymy is rare, because synonyms often have different distributions along a number of parameters. Synonymous forms differ in terms of dialect, formality, language, style, emotion, evaluative meanings, collocation restrictions, connotation and grammaticality among others. Ndebele is particularly rich in synonyms for the historical reason that its vocabulary has come from various languages, among them, Nguni varieties, English, Afrikaans, Kalanga, Shona and many others.

Synonymy is sometimes seen as a special type of hyponymy. It can be defined as symmetrical hyponymy (Yule 2006: 105). Yule describes this relationship using this sentence frame: If $X$ is a hyponym of $Y$ and $Y$ is a hyponym of $X$, then $X$ and $Y$ are synonyms. For example, scarlet/crimson is a hyponym of red, and buy a hyponym of get, implying or entailing that these are synonyms.

\section{Hyponymy, meronymy and synonymy and the treatment of meaning in ISN}

When definitions in ISN are considered, it emerges that hyponymy has been extensively and effectively used in defining headwords. How ISN compilers have utilized hyponymy in their definitions, can be illustrated by the following selected ISN definitions of semantic sets:

(5) umlaza bz 3. Umlaza ngamayezi angahlangananga.

(cirrus noun cl 3. Cirrus are clouds that are scattered in the sky.)

(6) indlondlo bz 9. Indlondlo yimamba eluhlaza ehlala ezihlahleni elolaka kakhulu. (green mamba noun cl 9. A green mamba is a green type of snake of the mamba family that is very vicious and lives in trees.) 
Many headwords in ISN are defined using the notion that hyponyms are a kind or type of a specific hypernym. The definitions of the headwords provide the hypernym together with various distinguishing hyponymic features. Although only a few examples of such definitions can be given, it appears that hyponymy forms the core relationship within the dictionary.

An evaluation of the treatment of meaning in ISN reveals that the definitions of headwords have been structured in a manner reflecting the extensive application of meronymy too. The definitions of the following ISN entries show the use of meronymy:

(7) ixolo bz 5.1 Ixolo yingxenye yesihlahla evikela umzimba waso. 2 ...

(bark noun cl 5. 1 Bark is the outer covering of a tree that protects its trunk. 2 ...)

(8) ilunga bz 5. 1 Ilunga yingxenye yolutho, ikakhulu imfe. 2 ...

(joint noun $\mathrm{cl} 5.1 \mathrm{~A}$ joint is a part of a something, for example the stem of the sweet reed. 2 ...)

(9) isiduku bz 7. Ingxenye yenduku okutshaywa ngayo esakhanda layo yisiduku.

(knob noun cl 7. The thicker round end of a knobkerrie that is used for hitting is the knob.)

Following the application of the notions of hyponymy and meronymy in the evaluation of the treatment of meaning in ISN, one notes that these sense relations are a useful and an important defining format. Using hyponymy and meronymy facilitates defining the headword. According to Landau (2001: 162), the definition must define and not just speak about the word or its usage. It must answer the question "What is it?" directly and immediately. The definition must not fail in its basic purpose of giving users enough direct and immediate information to enable them to surmise, at least approximately, its meaning in context.

For example, to say ulude (greens) ngumbhida (are a type of vegetable) or umthala (the thick muscles) yingxenye yolusu (are part of the stomach of cattle), form the first and most important part of this essential principle of defining. Various distinguishing features of ulude as a type of vegetable and umthala as part of the stomach of cattle further explain and define them. This approach to defining decomposes the meaning of a word and describes it with a meaningful sequence of words, which makes the definition more accessible and specific. It leads to accurate and precise definitions, which are the aim of every lexicographer. Moreover hyponymy and meronymy help the lexicographer adhere to good defining practices, especially that of the prioritization of its characteristics, where the most essential elements of meaning come first while the more incidental ones come later. When hyponymy and meronymy is used in defining, the essential elements of the meaning of the headword are stated immediately and directly. For example, to define ikhasi (page) as ingxenye yogwalo yokulobela (the internal part of a book) or umkhiwa (wild fig) as yisithelo seganga (a wild fruit tree), immediately and directly brings forward the essential ele- 
ments of the meaning of ikhasi and umkhiwa respectively. Hyponymy and meronymy guarantee simple and straightforward definitions characteristic of a user-friendly dictionary. An application of hyponymy and meronymy in defining helps one adhere to the essential principles of defining, guarding against circularity and repetition.

Hyponymy and meronymy also prove to be a solution to defining taboo and/or offensive words that appear to have been a problem for ISN compilers. For example, the lexicographer can adopt an approach of entering the culturally acceptable synonyms of the taboo and/or offensive word as the main entries that carry the entire definition and use these synonyms as cross-references indicating their tabooness and/or offensiveness. The definitions of the main entries could be structured as shown in the following examples proposed by the author to illustrate the usefulness of hyponymy and meronymy in defining taboo and/or offensive words.

(10)(a) iphambili bz 5. Iphambili yisitho sensitha sezidalwa zesilisa loba ezinduna esigcina njalo sidale inhlanyelo loba ubudoda. FAN isende.

(private part noun cl 5. A private part is a reproductive organ of males that stores and produces semen. COMP isende.)

(b) isende bz 5. Isende ligama elingahloniphiyo elitsho iphambili alithiwa bhadla emphakathini. BONA iphambili.

(testicle noun cl 5. Testicle is a taboo word that refers to a private part of males, and it cannot be used in public. SEE iphambili.)

Hyponymy and meronymy yield definitions that are more explicit about and representative of the content aspect of the entry since they allow the lexicographer to be as specific as wished. They are fundamental to semantic analysis of lexemes in lexicography because they express the basic logical relationships that are represented widely throughout the lexicon.

ISN definitions reveal that synonymy has been extensively used in defining a number of headwords. A look at a selected sample of verbs and taboo words in ISN shows the extent to which ISN compilers have used synonymy as a defining format:

(11) -zonda sz mwa. 1 ... 2 Ukuzonda yikucaphuka lokufuthelana emoyeni.

(hate transitive verb. 1 .. 2 Hate is to have a strong feeling of dislike and emotional frustration.)

(12) isende bz 5. Isende liphambili lowesilisa njalo kulapho okulenhlanyelo yobudoda. Igama leli liyahloniphisa alikhulunywa emphakathini nje.

(testicle noun cl 5. A testicle is a male person's reproductive organ where semen is stored. This term is a taboo word; it cannot be used in public.)

(13) -thwala sz gmwa. Nxa izulu lithwala liyabe lihloma selilungela ukuna.

(condense intransitive verb. When clouds condense they would be building up ready for a shower of rain.) 
For illustrative purposes these three definitions suffice to support the observation that synonymy was extensively used as a defining format for quite a number of headwords in ISN.

To assess the contribution(s) that synonymy makes to user-friendliness, accessibility of definitions and semantic analysis of headwords in lexicography, it must be considered whether synonym definitions contribute to the essential principles of defining, ensuring the compilation of clear, systematic, straightforward and specific definitions, which are culturally and contextually appropriate and relevant, making dictionaries user-friendly and accessible. For the assessment of the use of synonymy in dictionaries, it is necessary to redefine what a synonym is in lexicographic contexts. The definition to be adopted for lexicography is that of Wiegand (1983: 146) which views lexical synonymy as the occurrence between two lexical items when the rules of usage are to such an extent similar that the rules of reference and predication are the same in habitual texts.

With regard to standard or smaller general monolingual dictionaries, the prevailing view is that synonym definitions are necessary. Landau (2001: 398) states that synonym definitions are not necessarily a mark of slack or inept editing, rather they may be the best solution to the problem of too little space. Sharing the same opinion, Svensén (1993: 119) also notes that the use of synonyms and near synonyms as definitions save space. They are entirely valid when the need for semantic precision is not too great, but one has to be on guard against polysemous synonyms. Words used in the context of the definition must be unambiguous. In other words, as Hanks (1987: 116) rightly puts it, the definition must be clear and unambiguous. If a word used in the definition is polysemous, the particular sense in which it is intended must be made clear by the rest of the definition (Landau 2001: 170). However, if it is considered that synonym definitions are only one-word definitions, there is no possibility for a definition that will explain the particular sense intended for the polysemous word, as is the case with the following ISN entries ishinga (rascal) and amachaphazi (larvae). For these entries the polysemous synonyms ongezwayo and izibungwana respectively are presented as complete definitions. The word ongezwayo can be interpreted in two ways, meaning either someone who is naughty or stubborn (isigholo) and/or someone who is deaf (isacuthe), which is the primary sense of ukungezwa. The word izibungwana can be taken to signify either the early stages of an insect's development or small insects (in the diminutive sense), which is the primary meaning of izibungwana. A quick glance through ISN reveals that avoidance of ambiguous words was often overlooked. Synonyms cannot be used as definitions unless they are disambiguated through exemplification or contextualization. Although the sense of these defining words captures the meaning of the headwords they define, the use of polysemous synonyms ambiguates the definition, compromising the dictionary's accuracy and accessibility of its definitions. If it is considered that space is limited in most dictionaries, especially in dictionary types like ISN 
which are general-purpose dictionaries, examples are kept as minimal as possible, hence synonym definitions prove to be an inexact way of specifying the meaning of words.

Svensén (1993: 119) stresses that if a synonym is polysemous, it must not be given as a complete definition, but must be disambiguated. Adopting Svensén's stance of disambiguation through the addition of further synonyms is also problematic not only because it wastes space as the words used in the definition must also be entered and defined, but also because it compromises precision since the words used in the definitions are partial synonyms. In addition to these problems, this approach takes up users' time for they have to go to at least three or more distinct but related entries.

This type of synonym definitions furthermore yields culturally unacceptable definitions that are inaccurate and imprecise since these words cannot be used interchangeably in all contexts. Evaluated according to the adopted lexicographic definition of lexical synonymy that upholds the rules of usage, reference and predication, ISN definitions identified as culturally inappropriate and unacceptable are those that use a class of synonyms whose contextual differences are great and their interchangeability impossible, causing embarrassment to speakers and writers. In this way, the value of the dictionary is compromised as a trusted and respected repository of facts about a language and its culture, and as a decisive authority on "good" as opposed to "bad" usage. In addition to this, the use of ambiguous synonym definitions causes the dictionary to fail as a guardian of the moral and ideological values of the society (Béjoint 2000: 124). A dictionary must reflect these societal values in some aspects of its macrostructure and microstructure, particularly the selection and presentation of headwords, the wording of definitions and the choice of examples. Apart from yielding culturally inappropriate and unacceptable definitions, use of synonym definitions in ISN lead to unnatural circumlocutory definitions. This can be illustrated by the following ISN examples:

(14)(a) -khwela sz mwa. Leli ligama lokuhlonipha elitsho ukuzeka. FAN zeka. (mate transitive verb. This is a taboo word that refers to having sexual intercourse. COMP sexual intercourse.)

(b) -zeka sz. Uma inkunzi ikhwela inkomokazi iyabe iyizeka.

(have sexual intercourse transitive verb. When a bull is covering a cow, it will be having sexual intercourse.)

The above definitions do not define the entry by answering the question "What is it?" directly and immediately. These two words cannot be used interchangeably since -khwela (cover) only refers to animals and -zeka (have sexual intercourse) is a taboo word used only in respect of humans; therefore they cannot define each other.

Commenting on circularity, Landau (2001: 157) notes that, since the primary purpose of a dictionary is to inform users of the meaning of words, any- 
thing that denies them this information makes a dictionary defective. Circularity does not just complicate the consulting process, it makes it impossible. No amount of diligence on the part of users can overcome the barrier of circularity (Svensén 1993: 33). The use of synonym definitions often results in inaccurate definitions. Near-synonyms compromise precision and at times the cultural relevance of the definition, leading to miscommunication as in defining $u k u$ khuluphala (being stout) with ukunona (being fat) or vice versa. Although these words refer to the same quality, the former refers to humans only while the latter refers to animals only. A similar case is -zaca (become slim) which in ISN has been cross-referenced to -caka (become thin). These two headwords cannot be used interchangeably since the former refers to humans only while the latter refers to animals only. In this way, the value of the dictionary as a tool for improving communication is compromised.

A definition must not fail its basic purpose of giving users enough direct and immediate information to enable them to surmise, at least approximately, its meaning in context. Definitions compromising the principle of defining the entry lengthen the consultation process by sending users to more than one entry, a procedure which most, if not all, users are unwilling to follow. The following ISN definitions could be considered as examples:

(15)(a) -khathaza sz mwa. Nxa ukhathaza uyabe uhlupha abanye abantu. (pester transitive verb. If you are pestering other people, you will be bothering them.)

(b) -hlupha sz mwa. Nxa uhlupha uyabe uphatha kabi abanye abantu usenza badubeke.

(bother transitive verb. If you are bothering people you will be treating them badly making them suffer.)

(16)(a) inhlanhla bz 9.1 ... 2 Inhlanhla lithamsanqa lokusinda engozini.

(luck noun cl. 19. A stroke of luck is to be fortunate to survive an accident.

(b) ithamsanqa bz 5. Ithamsanqa yinhlanhla engalindelwanga eyehlela umuntu. (fortune noun cl 5. Fortune is unexpected luck which happens to someone.)

(17)(a) -depha sz gmwa. Ukudepha yibude kumbe ukutshona kolutho phansi. (to have depth intransitive verb. How much depth something has, is how far it goes down into the earth.

(b) -tshona sz gmwa. 1 .. 2 Ukutshona komgodi yisilinganiso sawo sokudepha usiya phansi.

(to be deep intransitive verb. 1 ... 2 How deep a hole is, is how far it goes down from the surface.)

The above definitions compromise the principle of defining the entry by sending users to other entries which they also find defined circularly. Examples (15)-(17) are defined by their synonyms, -hlupha (bother), inhlanhla (luck) and 
-depha (deep) respectively. Béjoint (2000: 193) reiterates that simple equivalences or synonyms make the definitions inaccessible as compared to those that decompose the meaning of a word using an analytic definition which is more accessible to users.

Wiegand (1983: 150) argues that the use of synonyms and antonyms as definitions can be acceptable in dictionaries of synonyms or antonyms or when for one reason or another the analytic type does not work in dictionaries, which are not dictionaries of synonyms or antonyms. In his view synonym and antonym definitions are not definitions at all. According to him, synonyms belong in the semantic commentary yet not in the semasiological, but in the onomasiological part where they are best listed under an explicit cross-reference for synonyms, for example, 'FAN' or 'COMP' which can be understood as semantic commentaries functioning as cross-references.

Synonyms are a necessary part of the information that a dictionary must contain, hence they must be included. Fieldwork findings by Nkomo (2003: 44) reveal that synonyms are an important information category to the ISN users as $60 \%$ of the informants interviewed expect to find information on synonymy in Ndebele dictionaries. This shows synonyms to be an important component of the ISN microstructure. In including them, they must be printed in such a way that the letter type differs clearly from that of the meaning explanation. In as much as meaning is relational, a structural semantic definition, while important, still does not contain the full information, it cannot serve as a complete definition. In this regard, synonyms are not definitions, but serve as supplements to the lexicographic meaning explanation. Synonym definitions give users intralinguistic knowledge and deny them extralinguistic knowledge. As it is difficult to use a word without some extralinguistic knowledge, it must be combined with intralinguistic knowledge if users are to genuinely claim they know the entry. Synonyms are best used as cross-references, which help, apart from saving users' time, avoid compromising the essential defining principles and avoid unnecessary repetition of definitions.

From the outset it is important to establish and follow a set way of handling synonyms. The selection of synonyms as entries in ISN often violates its style manual, which stipulates that synonyms will be avoided as much as possible in definitions and will be included after the definition proper. With regard to headword selection, only indigenous synonyms will carry the entire definitions with the borrowed ones being used as cross-references. Compromising the stipulations of the style manual lead to inconsistencies both in the selection of synonyms as entries and their use as cross-references, making it difficult to master the microstructure and to use the dictionary efficiently.

As Zgusta (1971: 248) rightly points out, the presentation and treatment of the information need to be consistent if the dictionary is to be user-friendly and accessible. A cursory look through ISN reveals inconsistencies in the selection of synonyms as headwords and their use as cross-references. In some cases users are sent to entries that are not entered in the dictionary or are sent back to 
the entries with which they started. Examples (15)-(17) show such circular definitions.

Synonym definitions also compromise the defining principle of using common, everyday words. Landau (2001: 157) states that the lexical definition should not contain words "more difficult to understand" than the word being defined. Using "more difficult words" to define the entry wastes space since every word used in the definition must be entered. For these it would be necessary to formulate a clearer definition that will simplify the "more difficult entry". When using a general monolingual dictionary, users would expect that, if they do not know the meaning of a word used in a definition, they can look up that word and find it defined. The use of words which are not common everyday words compromises the naturalness of definitions, making them more difficult to understand (Moon 1987: 89). As far as ISN is concerned, the principle of defining using common, everyday words is compromised. When these "more difficult words" are entered and defined, in some cases they are defined circularly and in some cases users are referred back to the very entry with which they started. For example, inhlanhla (luck) is defined using the less common word ithamsanqa (fortune), which as headword is explained circularly with the word it defines. In fact, the first definition of inhlanhla accurately captures the meaning of these two absolute synonyms; it will therefore be proper just to use ithamsanqa as a cross-reference. Another example is -tshona (to be deep) which is defined using the less common word -depha (to have depth) which as headword is explained circularly with the word it defines. The practice of defining using less common words makes it difficult for users to understand the definitions.

\section{Relationship between sense relation, semantic field theory and com- ponential analysis}

A close look at hyponymy reveals that the idea of semantic field theory is also found in it. On a very general level, one can say that the words in a semantic field, though not synonymous, are all used to speak about the same general phenomenon. There is a meaning inclusion relation between the items in the field and the field category itself. The study of word meaning reveals that the lexicon of a language is not simply an unorganized list of words. Semantic relations such as hyponymy, meronymy, synonymy and antonymy are all involved in semantic fields, serving to link certain words with other words. Hyponymy is often important in displaying the semantic relation between items within a lexical field. In short, co-hyponyms form a semantic field of a particular field. For example, the semantic field of inyoka (snakes) has as some of its members inhlathu (python), imamba (mamba), iphimpi (cobra), ibululu (puff adder) to name a few. A semantic field is also composed of meronyms. For example, the fingers make up a semantic field and so also the parts of the body. The notion of semantic field can therefore be extended to any set of terms with 
a close relation in meaning, all of which can be subsumed under the same general label. The field then becomes the context within which to establish meaning relations. A semantic field makes it possible to ascertain meaning relations between words sharing the semantic space.

Not only does hyponymy relate with semantic field theory, it also relates with componential analysis in terms of logical inclusion. The idea of entailment involved in hyponymy is also evident in componential analysis, which is an alternative way of establishing, or at least confirming sense relations. Components or semantic features are the factors, or contrastive elements, which it is necessary to posit in order to account for all significant meaning relations (Leech 1969: 20). Componential analysis is founded on the notion of semantic contrast - antonymy. The componential notation provides a simple characterization of semantic relationships of logical inclusion-hyponymy, logical exclusion-antonymy and synonymy seen in componential synonymy. Componential analysis goes some way in explicating semantic relations such as hyponymy, synonymy and antonymy. Semantic components are hypernyms of particular co-hyponyms, for example +human, +male and +female.

\section{Conclusion}

The close-knit relationship between sense relations, semantic field theory and componential analysis is evidence enough that these approaches are necessary parts of a semantic theory worth adopting in lexicography as a holistic approach to the analysis of the meaning of lexemes. It can help account for more than a selection of semantic facts of lexemes in lexicography, and above all help adhere to the essential principles of defining. A holistic approach to meaning can go a long way in approaching meaning from a lexicographer's point of view. Reference on its own is not enough to specify the meaning of an entry in lexicography, for meaning encompasses both the intra- and extralinguistic elements of the entry. Hyponymy and meronymy form the basis of the analytic and classical definition, therefore lexicographers ought to consider them in their formulation of dictionary definitions in order to adhere to the essential principles of defining. On the other hand, as Landau (2001: 398) argues, synonym definitions waste, instead of saving space. They compromise the essential principles of defining, particularly that of defining the entry addressing the question "What is it?" directly and immediately, which in turn leads to circular, imprecise, inaccurate and culturally irrelevant definitions. In this regard, synonym definitions compromise the dictionary's user-friendliness and accessibility. They fail in their basic purpose to give users enough immediate information to enable them to surmise, at least approximately, the entry's meaning in context. In addition to the above, use of synonym definitions in monolingual general-purpose dictionaries lead to miscommunication. They prove to be an inexact way of specifying meaning, especially in dictionary types which are not synonym dictionaries. They take up time as users are sent to at least more than 
two entries, therefore disrupting the activity in which they are engaged. Hyponymy and meronymy prove to be productive and useful defining formats that help the lexicographer adhere to the essential principles of defining, in this way facilitating the user-friendliness and accessibility of the dictionary. Hyponymy and meronymy can also be useful formats for defining taboo and/or offensive words which proved problematic for ISN compilers and also prove to be a challenge in languages having the hlonipha variety (employed to show respect).

\section{References}

Béjoint, H. 2000. Modern Lexicography: An Introduction. Oxford: Oxford University Press.

Carnap, R. 1942. Introduction to Semantics. Cambridge, MA: Harvard University Press.

Carter, R. 1998. Vocabulary: Applied Linguistic Perspectives. London: Routledge.

Crystal, D. 1995. The Cambridge Encyclopedia of the English Language. Cambridge: Cambridge University Press.

Hadebe, S. et al. (Eds.). 2001. Isichazamazwi SesiNdebele. Harare: College Press.

Hanks, P. 1987. Definitions and Explanations. Sinclair, J.M. 1987: 116-136.

Jackson, H. 1988. Words and their Meaning. London/New York: Longman.

Landau, S.I. 2001. Dictionaries: The Art and Craft of Lexicography. Second Edition. Cambridge: Cambridge University Press.

Leech, G.N. 1969. Towards a Semantic Description of English. Harlow: Longmans.

Lyons, J. 1977. Semantics. Volume 1. Cambridge: Cambridge University Press.

Matthews, P.H. 1997. The Concise Oxford Dictionary of Linguistics. Oxford/New York: Oxford University Press.

Moon, R. 1987. The Analysis of Meaning. Sinclair, J.M. 1987: 86-103.

Nkomo, D. 2003. The Microstructure and the Accessibility of Dictionary Information: An Analysis of Isichazamazwi SesiNdebele. Unpublished B.A. Hons. Thesis. Harare: University of Zimbabwe.

Palmer, F.R. 1981. Semantics. Second Edition. Cambridge/London: Cambridge University Press.

Saeed, J.I. 2003. Semantics. Second Edition. Malden, MA: Blackwell.

Sinclair, J.M. (Ed.). 1987. Looking Up: An Account of the COBUILD Project in Lexical Computing and the Development of the Collins COBUILD English Language Dictionary. London: Collins ELT.

Svensén, B. 1993. Practical Lexicography: Principles and Methods of Dictionary-Making. Oxford/New York: Oxford University Press.

Ullmann, S. 1972. Semantics: An Introduction to the Science of Meaning. Oxford: Basil Blackwell.

Wiegand, H.E. 1983. Synonyms Appearing in Major Alphabetical Dictionaries of Contemporary German. Wiegand, H.E. 1999. Semantics and Lexicography. Selected Studies (1976-1996): 139152. Edited by A. Immken and W. Wolski. Tübingen: Max Niemeyer.

Yule, G. 2006. The Study of Language. Third Edition. Cambridge: Cambridge University Press.

Zgusta, L. 1971. Manual of Lexicography. The Hague/Paris: Mouton. 